DOI https://doi.org/10.30525/978-9934-26-040-7-4

\title{
СТАТУТ ЛАСЬКОГО 1506 Р.: АКТ ІНКОРПОРАЦІЇ ЗАКОНОДАВСТВА КОРОЛІВСТВА ПОЛЬСЬКОГО
}

\author{
Захарченко П. П. \\ доктор юридичних наук, \\ професор кафедри теорії та історії права та держави \\ Київського начіонального університету імені Тараса Шевченка
}

\section{Мірошниченко М. I.}

доктор юридичних наук,

професор кафедри теорії та історії права та держави

Київського начіонального університету імені Тараса Шевченка

м. Київ, Україна

Окремі дослідники історії польського права небезпідставно вважають, що у середньовічній Польщі воно набуло форм «державного права польської шляхти». У такому вигляді воно «гарантувало знаті їхні публічні прерогативи (свободи), їхні обов'язки перед королем і державою регулювались правовідносинами в межах шляхетського стану, а також ставленням до інших держав» [1]. Іншими словами, існуючі правовідносини в Польщі у центр своєї уваги ставили шляхетський стан як такий, що мав значні привілеї перед іншими соціальними групами та суспільними станами. Не лише не маємо до цього жодних заперечень, а усіляко підтримуємо науково обгрунтовану позицію вчених сусідньої країни. Відтак, маємо намір цією розвідкою показати досвід систематизації законодавства, що закладався у Польщі ще на початку XVI ст., та ознайомити європейського читача 3 правовою пам'яткою доби шляхетської демократії [2], що побачила світ у 1506 р., але свою назву отримала через півстоліття після опублікування. Вона названа на честь упорядника, одного 3 найвідоміших реформаторів Королівства Польського - великого коронного канцлера та примаса Польщі до 1510 р. Яна Ласького [3]. 3 ініціативи делегатів та за рішенням Радомського сейму 1505 р. він здійснив переклад відомих нормативних джерел $з$ латини на польську [4], упорядкував сеймові ухвали (конституції, привілеї тощо), окремі міжнародні договори, пам'ятки римського та магдебурзького права. Попри те, що розміщені в збірнику джерела магдебурзького права (Саксонске зерцало та 
Вайхбільд) були чинними на українських етнічних територіях, які входили до складу Королівства Польського, Статут Ласького залишається малодослідженим вітчизняним історично-правовим сегментом юридичної науки. До фрагментарної характеристики Статуту Ласького 1506 р. вдаються при підготовці навчальної літератури переважно історики права (І. Бойко, П. Захарченко, П. Музиченко, О. Нелін, I. Терлюк, Б. Тищик). Цілеспрямовано і результативно працює над дослідженням означеної тематики лише історик Т. Гошко-Зайцева, яка на двадцяти п'яти сторінках докторської дисертації дослідила біографію Яна Ласького, проаналізувала його правову спадщину та розвінчала міфи, що нагромадилися за останні сторіччя.

У історично-правовій науці досі не вироблено спільної думки щодо виду систематизації, здійсненого Яном Лаським. Переважна більшість дослідників як вітчизняних, так і польських вважають проведену королівським реформатором роботу не чим іншим як кодифікацією законодавства. Так, нині покійний одеський історик права П. Музиченко вказував, що в аналізований період у Польщі була відсутня єдина правова система, а Статут Ласького та Артикули Генріха Валуа не вирішували «проблему кодифікації права» [5].

Т. Гошко, своєю чергою, назвала дітище Яна Ласького першою спробою кодифікації польського права [6]. Януш Сондель висловлювався проти того, щоб Статут вважати реальною спробою кодифікації права в Польщі, бо хоч у ньому й містилися земські привілеї, статути, сеймові конституції, але його матеріал, мовляв, був укладений не за тематичним принципом, а за хронологічним. Вбачаємо хибність такого висновку, адже правилам та техніці систематизації це жодним чином не суперечить [7].

Один із авторів пропонованої розвідки не визначав виду систематизації, вказуючи лише на його поширення на території Галичини [8]. Проте глибше ознайомившись зі складовими Статуту Ласького, схиляємося до думки, що систематизація законодавства в Королівстві Польському відбулося у формі інкорпорації. Підставою для нашого судження $\epsilon$ той факт, що систематизація польського законодавства у 1506 р. відбулося за хронологічним принципом, без внесення змін до текстів і створення на їхній основі єдиного збірника права. Саме такі ознаки виділяє сучасна вітчизняна доктрина права, яка інкорпорацією законодавства визнає такий вид систематизації, що здійснюється за допомогою впорядкування нормативно-правових актів без зміни їхнього змісту шляхом зведення в єдині друковані видання (збірники, зібрання, довідники тощо) за хронологією та/або тематикою. Нові нормативно-правові акти або норми права внаслідок інкорпорації не 22 
3'являються; втручання в тексти актів можливе лише на рівні редакційної правки. Інкорпорація може здійснюватися як органами публічної влади (офіційна інкорпорація), так і іншими особами в межах їхньої діяльності, а також у наукових, навчальних та інших цілях (неофіційна інкорпорація) [9]. Систематизація Яна Ласького відноситься до категорії офіційної, адже вона виконувалася на підставі рішення делегатів сейму.

Статут Ласького 1506 р. є одним із перших друкованих та офіційно виданим зводом законів Королівства Польського, який складається із двох частин і має в українському перекладі, здійсненому Т. ГошкоЗайцевої, таку назву: «Спільний привілей славного Королівства Польського щодо конституцій і дозволів, що їх публічно встановив найясніший зверхник і володар пан Александр, Божою милістю король Польщі, великий князь Литви, володар і дідич Русі, Пруссії тощо, разом iз деякими правами, як божественними, так і людськими, які, однак, містяться не в самому привілеї, а долучені та приписані до того ж таки привілею $з$ власного королівського почину Його ясновельможності як заклик для повчання жителів королівства i для щасливого порядкування тим таки королівством і станом правосуддя в ньому; і які за дорученням Його ж таки священної величності якнайретельніше виправлені».

Лише перша частина систематизованого збірника польського законодавства була затверджена королем [4]. Беручи до уваги цілком авторитетну думку вченого В. Урущака, не можна не погодитися з тим, що ухвалення документу сеймом, надали обидвом частинам збірника статусу чинного джерела права. «Характер збірника як привілей короля Олександра, а фактично парламентська конституція цього правителя, видана за участю сенату та депутатів парламенту, зробили ії чинним кодексом права», - цілком резонно зазначав польський дослідник [10].

Попри те, що в назві збірника міститься термін «привілей», таке найменування в польській історіографії не прижилося. Ним у тогочасній польській правовій культурі позначався королівський правовий акт, записаний на пергаменті, засвідчений коронною печаткою. За своєю формою звід відповідав вказаним вимогам, адже призначена для короля Олександра копія була єдиною, на якій містилася коронна печатка, що унеможливлювала внесення будь-яких текстових змін та доповнень. Пишності цьому примірнику додавала високої художньої майстерності оздоблення та здійснене багатою рельєфною шкірою із застібками обрамлення. Окрім того, у друкарні Яна Халлера у Кракові було надруковано близько 150 примірників на паперових носіях [11]. За інформацію польської історіографії із названої кількості збереглося 
лише 53 примірники [12]. Для широкого використання у судовій практиці Статут був спрямований до всіх земель Королівства. Він також призначався для ознайомлення шляхти 3 досягненнями правової думки країни [13].

Аналіз систематизованих Яном Лаським матеріалів, роміщених у Статуті, дав підстави Т. Гошко-Зайцевій класифікувати їх за типом правових джерел. 3 одного боку, тут знайшли своє відображення раніше ухвалені сеймові закони (конституції) та індульти (привілеї, які папи видавали окремим особам), а з другого - так звані «права людські та Божі». Серед останніх авторка виділяє описи звичаєвого права Краківської землі; привілей для євреїв від 1264 р.; 14 рот присяг (присяга короля, шляхти, воєводи та васалів і усієї Молдавської землі, магістра, сенаторів, міщан Прусії тощо); окремі джерела кнонічного права; джерела міського права («Ius Civile Magdeburgensis», «Speculum Saxonum», «Summa utriusque Juris doctoris Raymundi») [14].

Статут Ласького, ухвалений на засіданні Радомського сейму залишався чинним як фундаментальна систематизація польської правової системи впродовж трьох століть, до кінця XVIII ст., коли Річ Посполита перестала існувати.

Викладене дає підстави на здійснення кількох узагальнень та висновків. 3 огляду на те, що галицькі етнічні українські території потрапили до складу Польщі у другій половині XIV ст., Статут Ласького 1505 р. як акт інкорпорації польського законодавства, став джерелом права і для західноукраїнських земель. Його чинність тут скасована лише на переломі XVIII і XIX ст., коли Річ Посполита перестала існувати, а ії землі були поділені між Російською імперією, Австрією та Пруссією.

\section{Література:}

1. Uruszczaк Wacław. In Polon Ia lex est rex. Polska na tle Europy XVI-XVII wieku. Konferencja Muzeum Historii Polski, Warszawa, 23-24 paz'dziernika 2006. S. 17.

2. Польща - нарис історії. Варшава, 2015. С. 57.

3. Камінський Сулима Анджей. Історія Речі Посполитої як історія багатьох народів, 1505-1795. Київ: Наш час, 2011. С. 39.

4. Picur Julia. O zbiorze Statuta y przywileje koronne z łacińskiego języka na polskie przełożone, nowym porządkiem zebrane, autorstwa Jana Herburta. repozytorium.uni.wroc.pl > Content > 04_01_J_Picur. (Дата звернення: 23.01.21).

5. Музыченко П. П. История государства и права Украины: Учеб. пособие. 6-е изд. испр. и доп. К.: Т-во «Знання», 2008. С. 154. 
6. Гошко Т. Ян Ласький та перші спроби кодифікації права в Польському Королівстві. Соиіум. 2017. № 13-14. С. 191.

7. Sondel J. Prawo rzymskie jako podstawa projektów kodyfikacyjnych w dawnej Polsce. Zeszyty prawnicze. 2001. № 1. S. 49.

8. Захарченко Петро. Історія українського права: Навч. посібник. К.: ВД «Освіта України», 2019. С. 146-147.

9. Теорія держави і права: підручник. https://pidru4niki.com/70677/ pravo. (Дата звернення: 23.01.21).

10. Uruszczak Wacław. Commune incliti Poloniae Regni privilegium constitutionum et indultuum. O tytule i mocy prawnej Statutu Laskiego z 1506 roku. http://www.law.uj.edu.pl/users/khpp/statut_laski.htm. (Дата звернення: 23.01.21).

11. Uruszczak W. Statut Łaskiego z 1506 roku. 500 lat tradycji państwa prawa w Polsce. Czasopismo Prawno-Historyczne. T. LIX. 2007. Z. 2. S. 13.

12. Uruszczak W. Commune incliti Poloniae Regni privilegium constitutionum et indultuum. O tytule i mocy prawnej Statutu Laskiego z 1506 roku. Zes zyty Naukowe Uniwersytetu Jagiellońskiego. T. XCVI. 2006. Z. 5. S. 113-114.

13. Statut Łaskiego z 1506 r. https://pamiecpolski.archiwa.gov.pl/statutlaskiego-z-1506-r. (Дата звернення: 23.01.21).

14. Зайцева Т. Д. Антропологія міст і міського права на руських землях Корони Польської в XIV - першій половині XVII ст. дис. на здобуття наукового ступеня док. іст. наук. К.: 2019. С. 113-114.

DOI https://doi.org/10.30525/978-9934-26-040-7-5

\title{
ВІЧОВІ ТРАДИЦІї НА РУСІ
}

\author{
Карпічков В. О. \\ кандидат юридичних наук, \\ асистент кафедри теорії та історії права та держави \\ Інституту права
}

Київького національного університету імені Тараса Шевченка м. Київ, Украӥна

Зародження демократичних інститутів і парламентаризму в Україні пов'язують $з$ Давньоруською державою, а саме 3 народним віче, як інститутом прямого народовладдя. Дослідження цього органу має 